\title{
The Impact of a Tank 40H Decant on the Projected Operating Windows for SB4 and Glass Selection Strategy in Support of the Variability Study
}

\author{
F.C. Raszewski \\ T.B. Edwards \\ D.K. Peeler
}

February 2008

Process Science and Engineering Section Savannah River National Laboratory Aiken, SC 29808 
WSRC-STI-2008-00017

Revision 0

\section{DISCLAIMER}

This report was prepared by Washington Savannah River Company (WSRC) for the United States Department of Energy under Contract No. DE-AC09-96SR18500 and is an account of work performed under that contract. Neither the United States Department of Energy, nor WSRC, nor any of their employees makes any warranty, expressed or implied, or assumes any legal liability or responsibility for the accuracy, completeness, or usefulness, of any information, apparatus, or product or process disclosed herein or represents that its use will not infringe privately owned rights. Reference herein to any specific commercial product, process, or service by trademark, name, manufacturer or otherwise does not necessarily constitute or imply endorsement, recommendation, or favoring of same by WSRC or by the United States Government or any agency thereof. The views and opinions of the authors expressed herein do not necessarily state or reflect those of the United States Government or any agency thereof.

Printed in the United States of America

Prepared For U.S. Department of Energy

The Savannah River National Laboratory is operated for the U.S. Department of Energy by Washington Savannah River Company. 
Keywords: $D W P F, S B 4$, decant, ARP

Retention: permanent

\section{The Impact of a Tank 40H Decant on the Projected Operating Windows for SB4 and Glass Selection Strategy in Support of the Variability Study}

F.C. Raszewski

T.B. Edwards

D.K. Peeler

February 2008

Process Science and Engineering Section Savannah River National Laboratory Aiken, SC 29808 


\section{REVIEWS AND APPROVALS}

\section{AUTHORS:}

F.C. Raszewski, Process Science and Engineering Section

Date

T.B. Edwards, Statistical Consulting Section

Date

D.K. Peeler, Process Science and Engineering Section

Date

\section{TECHNICAL REVIEWER:}

K.M. Fox, Process Science and Engineering Section

Date

APPROVERS:

R.E. Edwards, Manager, Process Science and Engineering

Date

C.C. Herman, Manager, Process Engineering Technology Group

Date

J.E. Occhipinti, Manager, Process Cognizant Engineering

Date

Waste Solidification Engineering 
WSRC-STI-2008-00017

Revision 0

\section{EXECUTIVE SUMMARY}

The Liquid Waste Organization (LWO) has requested that the Savannah River National Laboratory (SRNL) to assess the impact of a $100 \mathrm{~K}$ gallon decant volume from Tank $40 \mathrm{H}$ on the existing sludge-only Sludge Batch 4 (SB4) - Frit 510 flowsheet and the coupled operations flowsheet (SB4 with the Actinide Removal Process (ARP)). Another potential SB4 flowsheet modification of interest includes the addition of $3 \mathrm{wt} \%$ sodium (on a calcined oxide basis) to a decanted sludgeonly or coupled operations flowsheet. These potential SB4 flowsheet modifications could result in significant compositional shifts to the SB4 system. This paper study provides an assessment of the impact of these compositional changes to the projected glass operating windows and to the variability study for the Frit 510 - SB4 system. The influence of the compositional changes on melt rate was not assessed in this study nor was it requested.

Nominal Stage paper study assessments were completed using the projected compositions for the various flowsheet options coupled with Frit 510 (i.e., variation was not applied to the sludge and frit compositions). In order to gain insight into the impacts of sludge variation and/or frit variation (due to the procurement specifications) on the projected operating windows, three versions of the Variation Stage assessment were performed: (1) the traditional Variation Stage assessment in which the nominal Frit 510 composition was coupled with the extreme vertices (EVs) of each sludge, (2) an assessment of the impact of possible frit variation (within the accepted frit specification tolerances) on each nominal SB4 option, and (3) an assessment of the impact of possible variation in the Frit 510 composition due to the vendor's acceptance specifications coupled with the EVs of each sludge case.

The results of the Nominal Stage assessment indicate very little difference among the various flowsheet options. All of the flowsheets provide DWPF with the possibility of targeting waste loadings (WLs) from the low 30s to the low 40s with Frit 510. In general, the Tank $40 \mathrm{H}$ decant has a slight negative impact on the operating window, but DWPF still has the ability to target current WLs (34\%) and higher WLs if needed. While the decant does not affect practical WL targets in DWPF, melt rate could be reduced due to the lower $\mathrm{Na}_{2} \mathrm{O}$ content. If true, the addition of $3 \mathrm{wt} \% \mathrm{Na}_{2} \mathrm{O}$ to the glass system may regain melt rate, assuming that the source of alkali is independent of the impact on melt rate. Coupled operations with Frit 510 via the addition of ARP to the decanted SB4 flowsheet also appears to be viable based on the projected operating windows. The addition of both ARP and 3 wt $\% \mathrm{Na}_{2} \mathrm{O}$ to a decanted Tank $40 \mathrm{H}$ sludge may be problematic using Frit 510.

Although the Nominal Stage assessments provide reasonable operating windows for the SB4 flowsheets being considered with Frit 510, introduction of potential sludge and/or frit compositional variation does have a negative impact. The magnitude of the impact on the projected operating windows is dependent on the specific flowsheet options as well as the applied variation (e.g., frit specification, sludge variation, or both). The results of the traditional Variation Stage assessments indicate that the three proposed Tank $40 \mathrm{H}$ decanted flowsheet options (Case $\# 2-100 \mathrm{~K}$ gallon decant, Case $\# 3-100 \mathrm{~K}$ gallon decant and $3 \mathrm{wt} \% \mathrm{Na}_{2} \mathrm{O}$ addition and Case $\# 4-100 \mathrm{~K}$ gallon decant and ARP) demonstrate a relatively high degree of robustness to possible sludge variation over WLs of interest with Frit 510. However, the case where the addition of both ARP and $3 \mathrm{wt} \% \mathrm{Na}_{2} \mathrm{O}$ is considered was problematic during the traditional Variation Stage assessment. The impact of coupling the frit specifications with the nominal SB4 flowsheet options on the projected operating windows is highly dependent on whether the upper WLs are low viscosity or liquidus temperature limited in the Nominal Stage assessments. Systems that are liquidus temperature limited exhibit a high degree of robustness to the applied frit and sludge variation, while those that are low viscosity limited show significant reductions ( 6 percentage points) in the upper WLs that can be obtained. When both frit 
and sludge variations are applied, the paper study results indicate that DWPF could be severely restricted in terms of projected operating windows for the ARP and $\mathrm{Na}_{2} \mathrm{O}$ addition options.

An experimental variability study was not performed using the final SB4 composition and Frit 510 since glasses in the ComPro ${ }^{\mathrm{TM}}$ data base were identified that bounded the potential operating window of this system. The bounding ARP case was not considered in that assessment. After the flowsheet cases were identified, an electronic search of ComPro ${ }^{\mathrm{TM}}$ identified approximately 12 historical glasses within the compositional regions defined by at least one of the five flowsheet options, but the compositional coverage did not appear adequate to bound all cases. Therefore, SRNL recommends that a supplemental, experimental variability study be performed to support the various SB4 flowsheet options that may be implemented for future SB4 operations in DWPF. To support this recommendation, eighteen glasses have been selected based on the nominal sludge projections representing the current and proposed flowsheets over a WL interval of interest to DWPF (32-42\%). These eighteen glasses will be fabricated and characterized to demonstrate that the glasses are both acceptable and predictable by the current process control models for durability. SRNL will then be able to confirm the recommendation for the decant or $\mathrm{NaOH}$ addition based on applicability of the glass models and will also be able to confirm the processing window for coupled operations with Frit 510. 


\section{TABLE OF CONTENTS}

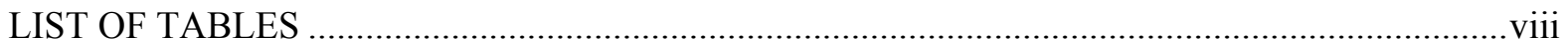

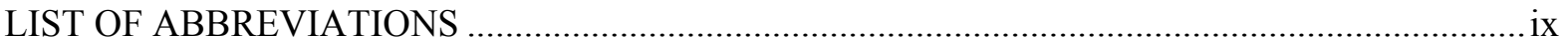

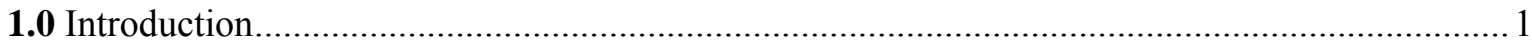

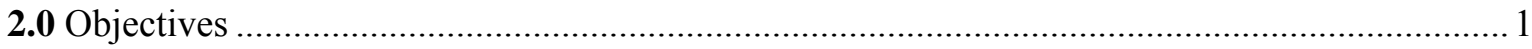

3.0 Measurement Acceptability Region (MAR) Assessments...................................................... 2

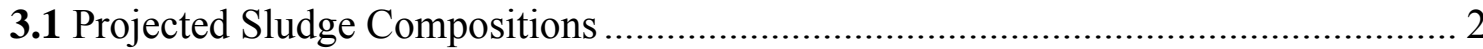

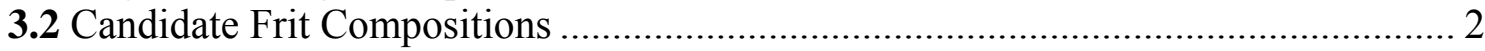

4.0 Nominal and Variation Stage Assessments ....................................................................... 4

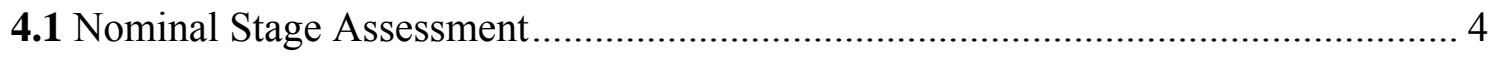

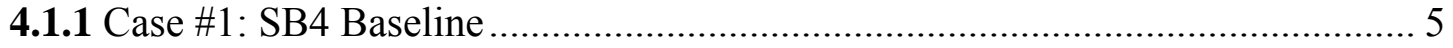

4.1.2 Case \#2: SB4 + 100K Gallon Decant …........................................................ 5

4.1.3 Case \#3: SB4 + 100K Gallon Decant $+3 \mathrm{wt} \% \mathrm{Na}_{2} \mathrm{O}$ Addition.......................... 6

4.1.4 Case \#4: SB4 + 100K Gallon Decant + ARP ............................................... 6

4.1.5 Case \#5: SB4 + 100K Gallon Decant $+3 \mathrm{wt} \% \mathrm{Na}_{2} \mathrm{O}$ Addition + ARP .............. 7

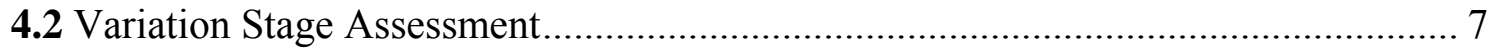

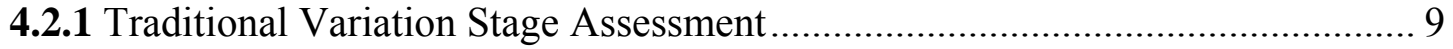

4.2.1.a Case \#1: SB4 Baseline ..................................................................... 9

4.2.1.b Case \#2: SB4 + 100K Gallon Decant ...................................................... 9

4.2.1.c Case \#3: SB4 + 100K Gallon Decant $+3 \mathrm{wt} \% \mathrm{Na}_{2} \mathrm{O}$ Addition.................. 10

4.2.1.d Case \#4: SB4 + 100K Gallon Decant + ARP .......................................... 10

4.2.1.e Case \#5: SB4 + 100K Gallon Decant $+3 w t \% \mathrm{Na}_{2} \mathrm{O}$ Addition + ARP .... 10

4.2.2 Frit 510 Specifications coupled with the Nominal Sludge Options................... 10

4.2.3 Frit 510 Specifications coupled with Sludge Variation ................................... 12

5.0 Impact of the SB4 Flowsheet Changes on the SB4 Variability Study .................................... 13

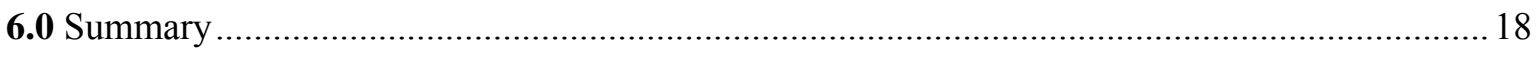

6.1 Nominal and Variation Stage Assessments .................................................. 18

6.2 Impact of the SB4 Flowsheet Changes on the SB4 Variability Study.................... 18

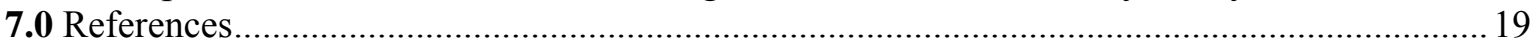




\section{LIST OF TABLES}

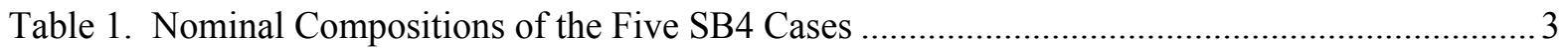

Table 2. Frit 510 Nominal Composition and Major Oxide Acceptance Specifications ....................... 3

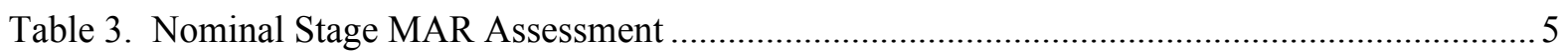

Table 4. Variation Stage Bounding Regions for Various SB4 Cases ............................................... 8

Table 5. Variation Stage (Sludge Variation Only) MAR Assessment .............................................. 9

Table 6. MAR Assessment of Frit 510 Specifications Coupled with Nominal SB4 Compositions.... 11

Table 7. MAR Assessment of Frit 510 Specifications Coupled with Sludge Variation...................... 12

Table 8. Target Glass Compositions (wt $\%$ ) for Case \#1 and Case \#3 ............................................. 15

Table 9. Target Glass Compositions (wt $\%$ ) for Case \#2 .............................................................. 16

Table 10. Target Glass Compositions (wt \%) for Case \#4 and Case \#5 ........................................... 17 


\section{LIST OF ABBREVIATIONS}

$\begin{array}{ll}\text { ARP } & \text { Actinide Removal Process } \\ \text { CPC } & \text { Chemical Process Cell } \\ \text { DWPF } & \text { Defense Waste Processing Facility } \\ \text { EV } & \text { Extreme Vertice } \\ \text { LWO } & \text { Liquid Waste Organization } \\ \text { MAR } & \text { Measurement Acceptability Region } \\ \text { MCU } & \text { Modular Caustic-Side Solvent Extraction Unit } \\ \text { MST } & \text { Monosodium Titanate } \\ \text { NL [B] } & \text { Normalized Leachate for Boron } \\ \text { PCCS } & \text { Product Composition Control System } \\ \text { PCT } & \text { Product Consistency Test } \\ \text { QA } & \text { Quality Assurance } \\ \text { SB4 } & \text { Sludge Batch 4 } \\ \text { SME } & \text { Slurry Mix Evaporator } \\ \text { SRAT } & \text { Sludge Receipt and Adjustment Tank } \\ \text { SRNL } & \text { Savannah River National Laboratory } \\ \text { TL } & \text { Liquidus Temperature } \\ \text { TTR } & \text { Technical Task Request } \\ \eta & \text { Viscosity } \\ \text { WAPS } & \text { Waste Acceptance Product Specifications } \\ \text { WL } & \text { Waste Loading (weight percent) } \\ \text { WT } & \text { Waste Throughput }\end{array}$


WSRC-STI-2008-00017

Revision 0

\subsection{Introduction}

Sludge Batch 4 (SB4) is currently being processed in the Defense Waste Processing Facility (DWPF) using Frit 510. The slurry pumps in Tank $40 \mathrm{H}$ are experiencing in-leakage of bearing water, which is causing the sludge slurry feed in Tank $40 \mathrm{H}$ to become dilute at a rapid rate. Currently, the DWPF is removing this dilution water by performing caustic boiling during the Sludge Receipt and Adjustment Tank (SRAT) cycle. In order to alleviate prolonged SRAT cycle times, which may eventually impact canister production rates, decant scenarios of varying amounts of supernate have been proposed for Tank 40H. The Savannah River National Laboratory (SRNL) has issued a preliminary assessment evaluating the possible downstream impacts of three (100, 150, and 200 kilogallon) decant scenarios on DWPF glass formulation and Chemical Processing Cell (CPC) issues. ${ }^{1}$ Based on the results of the preliminary assessment, the Liquid Waste Organization (LWO) issued a Technical Task Request (TTR) for SRNL to perform a more detailed evaluation using updated SB4 compositional information. ${ }^{2}$ As defined in the TTR, LWO has requested SRNL to validate the existing sludgeonly SB4 flowsheet and coupled operations ${ }^{\mathrm{a}}$ flowsheet for a $100 \mathrm{~K}$ gallon decant volume. Another potential SB4 flowsheet modification of interest to LWO included the addition of $3 \mathrm{wt} \%$ sodium (on a calcined oxide basis) to a decanted sludge-only or coupled operations flowsheet.

These potential SB4 flowsheet modifications (i.e., $100 \mathrm{~K}$ gallon decant, potential additions of $\mathrm{Na}_{2} \mathrm{O}$, and/or transitioning to a coupled operations flowsheet) could result in significant compositional shifts to the SB4 system. To meet the objectives of the TTR, SRNL performed an assessment of the impact of these compositional changes to the projected glass operating windows and to the variability study for the Frit 510 - SB4 system as defined in the Task Technical and Quality Assurance (QA) Plan.,

\subsection{Objectives}

The objectives of the current report are:

(1) To provide feedback to LWO regarding the impact of the proposed SB4 flowsheet changes (Tank $40 \mathrm{H}$ decant, $\mathrm{Na}_{2} \mathrm{O}$ addition, and/or transition to coupled operations) to the projected operating windows for the SB4 - Frit 510 system. The projected operating windows will be defined as the waste loading (WL) interval over which glasses are classified as acceptable based on current DWPF process control models and their associated acceptance constraints. The results presented in this report are solely based on model predictions and do not include any experimental work (such as melt rate assessments).

(2) To determine if a supplementary variability study is needed for the new compositional regions developed by the proposed SB4 flowsheet changes. The newly defined glass compositional regions will be compared to existing glass data (i.e., historical glasses) within the ComPro ${ }^{\mathrm{TM}}$ database. $^{4,5}$ If sufficient historical glasses are found within the compositional regions defined by the revised SB4 - Frit 510 flowsheet, then an experimental study may not be required. If an adequate number of historical glasses bounding the compositional range are not found, then an experimental study will be designed and implemented to support the Waste Acceptance Product Specifications (WAPS) requirements. A variability study will determine if the Product Consistency Test (PCT)/chemical composition correlation (i.e., $\Delta \mathrm{G}_{\mathrm{P}}$

\footnotetext{
${ }^{a}$ SB4 coupled with the Actinide Removal Process (ARP) / monosodium titanate (MST) and/or Modular Caustic-Side Solvent Extraction (CSSX) Unit (MCU) strip effluent.

${ }^{\mathrm{b}}$ As defined in the Task Technical and QA Plan, there are supplemental studies to evaluate the impact of these potential flowsheet changes on the CPC. These issues are not addressed in this report but will be documented elsewhere.
} 
model) currently utilized by DWPF applies to the modified SB4 glass composition region of interest. ${ }^{6,7}$

\subsection{Measurement Acceptability Region (MAR) Assessments}

In order to perform the model-based MAR assessments, two critical inputs are required: (1) projected sludge compositions for the proposed flowsheet changes (i.e., decant, $\mathrm{Na}_{2} \mathrm{O}$ addition, and/or transition to coupled operations) and (2) candidate frit compositions. Given these two inputs, glass compositional regions of interest can be defined and evaluated against existing Product Composition and Control System (PCCS) criteria to establish projected operating windows for the glass systems of interest. $^{8}$ The results of the MAR assessment will provide insight into the viability of the various flowsheet changes being considered for DWPF operations. ${ }^{9}$ The following sections will discuss and provide the nominal sludge composition projections, the nominal composition of Frit 510 (including major oxide specifications), and a high-level summary of the MAR assessment criteria utilized.

\subsection{Projected Sludge Compositions}

To support the MAR assessments, the nominal (baseline) SB4 composition, compositional projections of SB4 with the $100 \mathrm{~K}$ gallon decant, and SB4 with the $100 \mathrm{~K}$ gallon decant and a $3 \mathrm{wt} \%$ $\mathrm{Na}_{2} \mathrm{O}$ addition have been provided by LWO. ${ }^{\mathrm{c}}$ SRNL subsequently added the ARP/MCU stream ${ }^{\mathrm{d}}$ to these compositions to assess the scenarios that were presented in the TTR. The following five nominal SB4 sludges were identified to support this study:

Case \#1: SB4 Nominal

Case \#2: SB4 after the 100K gallon decant

Case \#3: SB4 after the $100 \mathrm{~K}$ gallon decant with a $3 \mathrm{wt} \% \mathrm{Na}_{2} \mathrm{O}$ addition

Case \#4: SB4 after the 100K gallon decant and with addition of ARP J

Case \#5: SB4 after the 100K gallon decant with the addition of $3 \mathrm{wt} \% \mathrm{Na}_{2} \mathrm{O}$ and ARP $\mathrm{J}$

Table 1 summarizes the nominal compositions of the five sludge options, which will be referred to as Case \#1 through Case \#5 throughout the remainder of this report.

\subsection{Candidate Frit Compositions}

Currently, Frit 510 is being used to process SB4. The nominal or targeted composition of Frit 510 (wt\% oxide basis) is listed in Table 2, as well as specifications of the four major oxides placed on the frit vendor for acceptance. ${ }^{10,11}$ It should be noted that this study does not consider additional oxide/halide impurities or their concentrations that are also a part of the specification. ${ }^{\text {e }}$

\footnotetext{
${ }^{\mathrm{c}}$ Compositional projections received on 1-4-08 via personal communication (email) from H.H. Elder. Note: $\mathrm{SO}_{4}$ values were not reported by LWO. The value reported during analysis of the WAPS sample $(1.336 \mathrm{wt} \%$ on a calcined oxide basis) was used for the nominal SB4 composition (prior to Tank $40 \mathrm{H}$ decant and/or addition of $\mathrm{Na}_{2} \mathrm{O}$ ). $\mathrm{The}^{\mathrm{SO}_{4}}$ value after decanting was assumed to be $\sim 25 \%$ less based on information reported by LWO in November 2007. Although the addition of $\mathrm{NaOH}$ to regain $3 \mathrm{wt} \% \mathrm{Na}_{2} \mathrm{O}$ in sludge would result in a small dilution in $\mathrm{SO}_{4}$ content of the decanted $3 \mathrm{wt} \% \mathrm{Na}_{2} \mathrm{O}$ projected composition, the $\mathrm{SO}_{4}$ content was not changed.

${ }^{\mathrm{d}}$ Compositional information for Appendix J was obtained from X-CLC-S-00113, Rev 0, Actinide Removal Process Material Balance Calculation with Low Curie Salt Feed, S.G. Subosits, 9/24/04, Appendix J.

${ }^{\mathrm{e}}$ In this report, an assessment is made to evaluate the impact of the compositional specifications for the four major oxides on projected operating windows. A supplemental study is being performed in parallel to this task in order to assess the possible impact of an "out of spec" frit (either major oxides or impurity levels outside of the current acceptance specification) on the projected operating windows for the five SB4 cases of interest. The results will be documented in a separate report.
} 
Table 1. Nominal Compositions of the Five SB4 Cases

\begin{tabular}{|c|c|c|c|c|c|}
\hline & Case \#1 & Case \#2 & Case \#3 & Case \#4 & Case \#5 \\
\hline & $\begin{array}{c}\text { SB4 } \\
\text { Baseline }\end{array}$ & $\begin{array}{l}\text { SB4 after } \\
\text { 100K } \\
\text { Decant }\end{array}$ & $\begin{array}{c}\text { SB4 after } \\
\text { 100K Decant } \\
\text { with Sodium } \\
\text { Added }\end{array}$ & $\begin{array}{l}\text { SB4 after } \\
\text { 100K } \\
\text { Decant + } \\
\text { ARP J }\end{array}$ & $\begin{array}{l}\text { SB4 after 100K } \\
\text { Decant }+ \\
\text { Sodium Added } \\
+ \text { ARP J }\end{array}$ \\
\hline $\mathrm{Al}_{2} \mathrm{O}_{3}$ & 24.894 & 25.958 & 25.015 & 24.988 & 24.091 \\
\hline $\mathrm{BaO}$ & 0.074 & 0.077 & 0.075 & 0.078 & 0.075 \\
\hline $\mathrm{CaO}$ & 2.730 & 2.857 & 2.753 & 2.765 & 2.666 \\
\hline $\mathrm{Ce}_{2} \mathrm{O}_{3}$ & 0.065 & 0.068 & 0.066 & 0.073 & 0.070 \\
\hline $\mathrm{Cr}_{2} \mathrm{O}_{3}$ & 0.155 & 0.162 & 0.156 & 0.160 & 0.154 \\
\hline $\mathrm{CuO}$ & 0.057 & 0.060 & 0.058 & 0.059 & 0.057 \\
\hline $\mathrm{Fe}_{2} \mathrm{O}_{3}$ & 28.294 & 29.602 & 28.526 & 28.747 & 27.724 \\
\hline $\mathrm{K}_{2} \mathrm{O}$ & 0.350 & 0.366 & 0.353 & 0.354 & 0.341 \\
\hline $\mathrm{La}_{2} \mathrm{O}_{3}$ & 0.049 & 0.051 & 0.049 & 0.052 & 0.050 \\
\hline $\mathrm{MgO}$ & 2.685 & 2.809 & 2.707 & 2.676 & 2.579 \\
\hline $\mathrm{MnO}$ & 5.682 & 5.945 & 5.729 & 5.878 & 5.673 \\
\hline $\mathrm{Na}_{2} \mathrm{O}$ & 20.521 & 17.319 & 20.289 & 18.448 & 21.272 \\
\hline $\mathrm{NiO}$ & 1.574 & 1.647 & 1.587 & 1.633 & 1.576 \\
\hline $\mathrm{PbO}$ & 0.062 & 0.065 & 0.063 & 0.068 & 0.066 \\
\hline $\mathrm{SO}_{4}$ & 1.319 & 0.992 & 0.992 & 1.086 & 1.086 \\
\hline $\mathrm{SiO}_{2}$ & 2.662 & 2.785 & 2.683 & 2.681 & 2.585 \\
\hline $\mathrm{TiO}_{2}$ & 0.038 & 0.040 & 0.039 & 1.337 & 1.336 \\
\hline $\mathrm{U}_{3} \mathrm{O}_{8}$ & 8.633 & 9.032 & 8.704 & 8.747 & 8.435 \\
\hline $\mathrm{ZnO}$ & 0.077 & 0.081 & 0.078 & 0.081 & 0.078 \\
\hline $\mathrm{ZrO}_{2}$ & 0.079 & 0.083 & 0.080 & 0.088 & 0.086 \\
\hline
\end{tabular}

Table 2. Frit 510 Nominal Composition and Major Oxide Acceptance Specifications

\begin{tabular}{||c|c|c||}
\hline Oxide & wt \% & Specification ( $\mathbf{w t} \%)$ \\
\hline $\mathrm{B}_{2} \mathrm{O}_{3}$ & 14 & 0.85 \\
\hline $\mathrm{Na}_{2} \mathrm{O}$ & 8 & 0.55 \\
\hline $\mathrm{Li}_{2} \mathrm{O}$ & 8 & 0.55 \\
\hline $\mathrm{SiO}_{2}$ & 70 & 1.30 \\
\hline
\end{tabular}


WSRC-STI-2008-00017

Revision 0

\subsection{Nominal and Variation Stage Assessments}

Paper study assessments of sludge/frit systems are typically completed in a two-step process. The Nominal Stage assessment is a screening tool that is typically applied to a large set of candidate frits and/or sludge compositions to identify candidate flowsheets for further study, whereas the Variation Stage is a more thorough assessment of the sludge and is conducted for a select set of flowsheet options. Utilization of both of these stages allows for a detailed assessment of the impacts of sludge and/or frit variation on the projected operating windows of the system.

In each stage, glass compositions were generated to represent combinations of each sludge and Frit 510 at waste loadings of interest. The acceptability of the model predictions for a particular glass composition for either stage was judged by employing the same criteria that are used by the PCCS during Slurry Mix Evaporator (SME) acceptability decisions implemented in DWPF. ${ }^{9}$ Properties predicted for this assessment were determined to be acceptable by satisfying their respective MAR limits. This assessment is valuable because it mirrors the process used by DWPF for the same glass during SME acceptability decisions for future facility operations.

\subsection{Nominal Stage Assessment}

In this assessment the nominal sludge compositions were coupled with the nominal Frit 510 composition over WLs of $25-50 \%$ in increments of 1 percentage point resulting in 26 glasses for each system of interest. Projected operating windows were identified as the WL interval over which the glasses met all PCCS MAR criteria. For each glass, the property predictions assessed included those for liquidus temperature $\left(T_{L}\right)$, viscosity $(\eta)$, durability (normalized leachate for boron, NL[B]), $\mathrm{Al}_{2} \mathrm{O}_{3}$ and/or sum of alkali and their associated constraints ${ }^{\mathrm{f}}$, high viscosity (highv), low viscosity (lowv), high chromia concentration $\left(\mathrm{Cr}_{2} \mathrm{O}_{3}\right)$, high sulfate concentration $\left(\mathrm{SO}_{4}{ }^{2-}\right)$ and nepheline formation. The MAR assessments were based on the current version of PCCS. ${ }^{9}$

Table 3 summarizes the Nominal Stage assessment for each of the five flowsheet options of interest. To aid in the interpretation of Table 3, consider Case \#1; nominal Frit 510 coupled with nominal (or baseline) SB4 prior to the decant. This option reflects current operations at DWPF. The projected operating window is $27-42 \%$ WL with both low $\eta$ and nepheline formation predictions limiting access to WLs greater than $42 \%$. Homogeneity restricts access to the lower WLs $(25-26 \%)$; however, this is of no practical concern.

The "Constraint at Higher WLs" column of Table 3 has been included to provide the LWO and DWPF with the WL at which nepheline formation is predicted to become an issue for the flowsheets of interest. It should be noted that for Case \#1, nepheline is a primary constraint (in addition to low viscosity) and dictates the upper WL of the projected operating window. $\mathrm{T}_{\mathrm{L}}$ predictions become restrictive at higher WLs (greater than 45\%) for this system. Although not a concern from an

\footnotetext{
${ }^{\mathrm{f}}$ For sludge-only processing, the $\mathrm{Al}_{2} \mathrm{O}_{3}$ and sum of alkali constraints can be used to replace the homogeneity constraint and its auxiliary constraints (low frit, high frit) (Herman et al. (2002)). Although DWPF is currently operating a sludge-only flowsheet, the algorithms in PCCS still contain homogeneity (at the PAR) and the auxiliary constraints. Although there is a high probability that the $\mathrm{Al}_{2} \mathrm{O}_{3}$ and sum of alkali could also replace homogeneity and the auxiliary constraints for coupled operations, this report utilized the exact algorithms currently imposed in PCCS to assess the projected operating windows. It should be noted that this does create a potentially conservative evaluation on the projected operating windows for those systems found to be homogeneity limited at lower WLs or where predicted issues associated with its auxiliary constraints occur at other WLs of interest. The application of the current PCCS system will not have an impact on the results or conclusions from this study.
} 
operational perspective, WLs of $42 \%$ or greater would not be targeted based on nepheline formation issues for Case \#1. The projected operating windows for the remaining sludge options (Case \#2Case \#5) are not nepheline limited. Identifying the WL at which nepheline predictions become restrictive helps LWO and DWPF to recognize when durability related concerns may become an issue. This information essentially provides insight into the "WL cushion" available between the upper WL defined by the process control models and the WL at which nepheline formation could potentially impact durability or SME acceptability decisions.

Table 3. Nominal Stage MAR Assessment

\begin{tabular}{|c|c|c|}
\hline $\begin{array}{c}\text { SB4 } \\
\text { Option }\end{array}$ & $\begin{array}{c}\text { Projected } \\
\text { Operating } \\
\text { Window (WL) } \\
\end{array}$ & $\begin{array}{l}\text { Constraint at } \\
\text { Higher WLs }\end{array}$ \\
\hline Case \#1 & $\begin{array}{c}\text { homog } \\
27-42 \% \\
\text { low } \eta / \text { nepheline }\end{array}$ & $\mathrm{T}_{\mathrm{L}}$ at $46 \%$ \\
\hline Case \#2 & $\begin{array}{c}25-41 \% \\
\mathrm{~T}_{\mathrm{L}} \\
\end{array}$ & $\begin{array}{c}\text { Nepheline at } \\
45 \%\end{array}$ \\
\hline Case \#3 & $\begin{array}{c}\text { homog } \\
26-42 \% \\
\text { low } \eta \\
\end{array}$ & $\begin{array}{c}\text { Nepheline at } \\
44 \%\end{array}$ \\
\hline Case \#4 & $\begin{array}{c}\text { homog } \\
27-42 \% \\
\mathrm{~T}_{\mathrm{L}} \\
\end{array}$ & $\begin{array}{c}\text { Nepheline at } \\
45 \%\end{array}$ \\
\hline Case \#5 & $\begin{array}{c}\text { homog } \\
28-40 \% \\
\text { low } \eta\end{array}$ & $\begin{array}{c}\text { Nepheline at } \\
43 \%\end{array}$ \\
\hline
\end{tabular}

A few general comments regarding the results of the Nominal Stage assessments are provided below for each case.

\subsubsection{Case \#1: SB4 Baseline}

Based on the nominal compositions, current operations in DWPF have a projected operating window of $27-42 \% \mathrm{WL}$, which is limited at $43 \% \mathrm{WL}$ by both low viscosity and nepheline. At the current WL target of $\sim 34 \%$, none of the current process or product performance properties are challenged. Although current DWPF operations at this WL are exceeding initial production expectations, there is some interest to assess the impact of WL on melt rate in an attempt to identify the WL which provides the maximum waste throughput for this flowsheet. The results of the MAR assessment indicate that DWPF has an opportunity to target WLs in the high 30s to low 40s in order to increase waste throughput; however, targeting higher WLs increases the risk of nepheline formation based on model predictions when coupled with the uncertainties associated with measuring or targeting WL in DWPF.

\subsubsection{Case \#2: SB4 + 100K Gallon Decant}

Implementation of the Tank $40 \mathrm{H}$ decant reduces the total $\mathrm{Na}_{2} \mathrm{O}$ in the sludge, which results in a lower $\mathrm{Na}_{2} \mathrm{O}$ content (total) in the glass and thus increased $\mathrm{T}_{\mathrm{L}}$ predictions, assuming the same WL. The projected operating window is $25-41 \%$, but becomes limited by $\mathrm{T}_{\mathrm{L}}$ at $42 \%$ due to the shift in the 
glass composition. Even though the projected operating window is slightly smaller than the Case \#1 baseline, the lower $\mathrm{Na}_{2} \mathrm{O}$ concentration suppresses nepheline formation to higher WLs $(45 \%)$ and increases viscosity predictions (at a fixed WL). These results indicate that the Tank $40 \mathrm{H}$ decant not only allows DWPF to continue to target the nominal 34\% WL, but provides access to WLs up to $41 \% \mathrm{WL}$ without the risk of nepheline formation. Even if DWPF targeted $40 \% \mathrm{WL}$ and due to uncertainties the WL was actually $42 \%$, the system would only be limited by $T_{L}$ and risk-based decisions could be made to continue processing because there would be no durability concerns.

Although the lower $\mathrm{Na}_{2} \mathrm{O}$ content of this system could be advantageous for higher WLs, the impact of the Tank $40 \mathrm{H}$ decant on melt rate is unknown (even at the nominal 34\% WL target of current operations). Historical trends have shown that glass systems with a higher $\mathrm{Na}_{2} \mathrm{O}$ content typically have higher melt rates (at a fixed WL) than those with a lower $\mathrm{Na}_{2} \mathrm{O}$ content; however, for SB4, the primary driver for melt rate has been linked to the increased $\mathrm{B}_{2} \mathrm{O}_{3}$ content of Frit 510. While the influence of $\mathrm{Na}_{2} \mathrm{O}$ on melt rate is potentially of lesser importance for higher Al-based sludges, operational data from DWPF would be beneficial to SRNL for future frit development activities.

\subsubsection{Case \#3: SB4 + 100K Gallon Decant + 3 wt\% Na $\mathrm{O}$ Addition}

Preliminary assessments ${ }^{\mathrm{g}}$ of the Tank $40 \mathrm{H}$ decant suggested a negative impact on the projected operating window. ${ }^{1}$ As a result, DWPF is interested in the option of adding $\mathrm{Na}_{2} \mathrm{O}$ back to the glass forming system after the decant through $\mathrm{NaOH}$ additions. ${ }^{2}$ As shown in Table 3, a $3 \mathrm{wt} \% \mathrm{Na}_{2} \mathrm{O}$ addition to the decanted SB4 flowsheet re-establishes the baseline flowsheet (Case \#1) in terms of projected operating windows. The projected operating window for Case \#3 is $26-42 \% \mathrm{WL}$ with predictions of low viscosity limiting access to higher WLs. For Case \#3, nepheline formation is predicted at WLs of $44 \%$ and greater, which could be advantageous for operations if higher WLs are warranted. If the Tank $40 \mathrm{H}$ decant is performed (Case \#2) and DWPF operations indicate that melt rate is reduced due to the lower $\mathrm{Na}_{2} \mathrm{O}$ content of the glass, this option (Case \#3) does provide the opportunity to increase melt rate through $\mathrm{NaOH}$ additions. This latter statement assumes that the source of $\mathrm{NaOH}$ does not affect how the sodium impacts melt rate and that $\mathrm{CPC}$ related issues (acid consumption, rheology, etc.) were addressed.

\subsubsection{Case \#4: SB4 + 100K Gallon Decant + ARP}

The addition of ARP to the decanted Tank 40H SB4 system yields a projected operating window of $27-42 \% \mathrm{WL}$ that is restricted by $\mathrm{T}_{\mathrm{L}}$. This operating window is very similar to Case \#1 and Case \#3. Nepheline is not predicted to become an issue until 45\% WL. ARP not only adds $\mathrm{TiO}_{2}$ to the glass systems, but also provides additional $\mathrm{Na}_{2} \mathrm{O}$. This additional $\mathrm{Na}_{2} \mathrm{O}$ replaces the $\mathrm{Na}_{2} \mathrm{O}$ removed during the decant (similar to the use of $\mathrm{NaOH}$ in Case \#3), resulting in a sludge composition similar (the primary exception being $\mathrm{TiO}_{2}$ content) to the baseline flowsheet (Case \#1). Increased concentrations of $\mathrm{TiO}_{2}$ in the glass increase $T_{L}$ predictions, which for a $T_{L}$ limited system, may decrease the projected operating window. Because projected operating windows of Case \#4 and Case \#1 are identical, it appears that the negative effects of $\mathrm{TiO}_{2}$ are offset by the $\mathrm{Na}_{2} \mathrm{O}$ from ARP, which generally lowers $T_{L}$ predictions. Although there is no significant impact on the projected operating window, the MAR assessment provides no insight into the potential impacts of ARP on melt rate.

\footnotetext{
${ }^{g}$ The results of the preliminary study resulted in projected operating windows for the SB4 baseline (pre-decant) and SB4 post-decant of $26-43 \%$ and $25-38 \%$ WL, respectively. Although the $38 \%$ upper WL for the post-decanted option would allow for continued operations at $34 \% \mathrm{WL}$, higher WLs may not be allowed.
} 


\subsubsection{Case \#5: SB4 + 100K Gallon Decant + 3 wt\% $\mathrm{Na}_{2} \mathrm{O}$ Addition + ARP}

Case \#5 represents the addition of both ARP and $3 \mathrm{wt} \% \mathrm{Na}_{2} \mathrm{O}$ to a decanted SB4 flowsheet. Based on the previous discussions, this flowsheet provides two sources of $\mathrm{Na}_{2} \mathrm{O}$ to replace the $\mathrm{Na}_{2} \mathrm{O}$ in the glass removed by the decant. It is possible that the additional $\mathrm{Na}_{2} \mathrm{O}$ could improve melt rate, assuming that the system is not overwhelmed by the increased alkali content to the point that it leads to primary concerns associated with durability, nepheline, or low viscosity. The results of the MAR assessments suggest a relatively large operating window $(28-40 \% \mathrm{WL})$, which becomes limited by low viscosity at $41 \% \mathrm{WL}$ and nepheline at $43 \% \mathrm{WL}$. Although this is a viable flowsheet based on nominal compositions, this option may become less attractive from a glass formulation perspective once variation is applied due to the presence of "excessive" alkali from the ARP and $3 \mathrm{wt} \% \mathrm{Na}_{2} \mathrm{O}$ addition.

\subsection{Variation Stage Assessment}

Variation was applied to the nominal concentration of each sludge component based on its projected value. For the major oxides $\left(\mathrm{Al}_{2} \mathrm{O}_{3}, \mathrm{Fe}_{2} \mathrm{O}_{3}, \mathrm{Na}_{2} \mathrm{O}\right.$, and $\left.\mathrm{U}_{3} \mathrm{O}_{8}\right)$, a variation of $\pm 7.5 \%$ was applied. A $\pm 0.25 \mathrm{wt} \%$ variation was applied to $\mathrm{CaO}, \mathrm{MgO}, \mathrm{MnO}$, and $\mathrm{NiO}$. The variation applied to the nominal $\mathrm{SO}_{4}{ }^{2-}$ value was $\pm 0.10 \mathrm{wt} \%$, while a $\pm 0.5 \mathrm{wt} \%$ variation was applied to $\mathrm{SiO}_{2}$ and $\mathrm{TiO}_{2}$. The remaining sludge components were grouped into a category called 'Others'. A variation of $0.25 \mathrm{wt} \%$ was applied to the total concentration of the 'Others' components. The compositions (minimum and maximum values) of SB4 Cases \#1 - \#5 with the applied variation are listed in Table 4.

Algorithms available in the statistical software package JMP ${ }^{\mathrm{TM}}$ Version 6.0.3 were used to determine the extreme vertices (EVs) or bounding compositions of the sludge region for each case. ${ }^{12}$ Frit 510 was then combined with each of the EVs generated for each flowsheet option at WLs from 25 to $50 \%$. The resulting glass compositions were determined to be acceptable if the properties satisfied the current PCCS MAR criteria, which is consistent with the Nominal Stage assessment.

In this report, three versions of the Variation Stage assessment were performed: (1) the traditional Variation Stage assessment in which the nominal Frit 510 composition was coupled with the EVs of each sludge, (2) an assessment of the impact of possible frit variation (within the accepted frit specification tolerances) on each nominal SB4 option, and (3) an assessment of the impact of possible variation in the Frit 510 composition (within the accepted frit specification tolerances) coupled with the EVs of each sludge case. For cases (2) and (3), EVs defined by the frit procurement specifications were developed by applying the same statistical algorithms used for defining sludge EVs. 
Table 4. Variation Stage Bounding Regions for Various SB4 Cases

\begin{tabular}{|c|c|c|c|c|c|c|c|c|c|c|c|}
\hline \multirow{3}{*}{ Component } & \multirow{3}{*}{ Variation } & \multicolumn{2}{|c|}{ Case 1} & \multicolumn{2}{|c|}{ Case 2} & \multicolumn{2}{|c|}{ Case 3} & \multicolumn{2}{|c|}{ Case 4} & \multicolumn{2}{|c|}{ Case 5} \\
\hline & & Min. & Max. & Min. & Max. & Min. & Max. & Min. & Max. & Min. & Max. \\
\hline & & (wt\%) & (wt\%) & $(w t \%)$ & $(w t \%)$ & (wt\%) & (wt\%) & (wt\%) & $(w t \%)$ & (wt\%) & (wt\%) \\
\hline $\mathrm{Al}_{2} \mathrm{O}_{3}$ & $7.50 \%$ & 23.03 & 26.76 & 24.01 & 27.91 & 23.14 & 26.89 & 23.11 & 26.86 & 22.28 & 25.90 \\
\hline $\mathrm{CaO}$ & $0.25 \mathrm{wt} \%$ & 2.48 & 2.98 & 2.61 & 3.11 & 2.50 & 3.00 & 2.52 & 3.02 & 2.42 & 2.92 \\
\hline $\mathrm{Fe}_{2} \mathrm{O}_{3}$ & $7.50 \%$ & 26.17 & 30.42 & 27.38 & 31.82 & 26.39 & 30.67 & 26.59 & 30.90 & 25.64 & 29.80 \\
\hline $\mathrm{MgO}$ & $0.25 \mathrm{wt} \%$ & 2.44 & 2.94 & 2.56 & 3.06 & 2.46 & 2.96 & 2.43 & 2.93 & 2.33 & 2.83 \\
\hline $\mathrm{MnO}$ & $0.25 \mathrm{wt} \%$ & 5.43 & 5.93 & 5.70 & 6.20 & 5.48 & 5.98 & 5.63 & 6.13 & 5.42 & 5.92 \\
\hline $\mathrm{Na}_{2} \mathrm{O}$ & $7.50 \%$ & 18.98 & 22.06 & 16.02 & 18.62 & 18.77 & 21.81 & 17.06 & 19.83 & 19.68 & 22.87 \\
\hline $\mathrm{NiO}$ & $0.25 \mathrm{wt} \%$ & 1.32 & 1.82 & 1.40 & 1.90 & 1.34 & 1.84 & 1.38 & 1.88 & 1.33 & 1.83 \\
\hline $\mathrm{SO}_{4}$ & $0.1 \mathrm{wt} \%$ & 1.22 & 1.42 & 0.89 & 1.09 & 0.89 & 1.09 & 0.99 & 1.19 & 0.99 & 1.19 \\
\hline $\mathrm{SiO}_{2}$ & $0.5 \mathrm{wt} \%$ & 2.16 & 3.16 & 2.29 & 3.29 & 2.18 & 3.18 & 2.18 & 3.18 & 2.09 & 3.09 \\
\hline $\mathrm{TiO}_{2}$ & $0.5 \mathrm{wt} \%$ & - & - & - & - & - & - & 0.84 & 1.84 & 0.84 & 1.84 \\
\hline $\mathrm{U}_{3} \mathrm{O}_{8}$ & $7.50 \%$ & 7.99 & 9.28 & 8.36 & 9.71 & 8.05 & 9.36 & 8.09 & 9.40 & 7.80 & 9.07 \\
\hline Others & $0.25 \mathrm{wt} \%$ & 0.76 & 1.26 & 0.80 & 1.30 & 0.77 & 1.27 & 0.76 & 1.26 & 0.73 & 1.23 \\
\hline
\end{tabular}




\subsubsection{Traditional Variation Stage Assessment}

Table 5 summarizes the results of the traditional Variation Stage assessment (i.e., nominal Frit 510 coupled with each set of sludge EVs). As expected, the projected operating windows are reduced when variation is applied to the sludge composition as compared to the Nominal Stage assessment. A general discussion of the traditional Variation Stage results for each case is provided below.

Table 5. Variation Stage (Sludge Variation Only) MAR Assessment

\begin{tabular}{||c|c|c|c||}
\hline $\begin{array}{c}\text { SB4 } \\
\text { Option }\end{array}$ & $\begin{array}{c}\text { Variation } \\
\text { Stage }\end{array}$ & $\begin{array}{c}\text { Projected } \\
\text { Operating } \\
\text { Window (WL) }\end{array}$ & $\begin{array}{c}\text { Constraints at Higher } \\
\text { WLs }\end{array}$ \\
\hline $\begin{array}{c}\text { Case } \\
\# 1\end{array}$ & $\begin{array}{c}\text { Nominal } \\
\text { Frit }\end{array}$ & $\begin{array}{c}\text { homog } \\
29-36 \\
\text { low } \eta\end{array}$ & Nepheline limited at $42 \%$ \\
\hline $\begin{array}{c}\text { Case } \\
\# 2\end{array}$ & $\begin{array}{c}\text { Nominal } \\
\text { Frit }\end{array}$ & $\begin{array}{c}\text { homog } \\
28-37 \\
\mathrm{~T}_{\mathrm{L}}\end{array}$ & $\begin{array}{c}\text { Low } \eta \text { limited at } 42 \%, \\
\text { nepheline limited at } 43 \%\end{array}$ \\
\hline $\begin{array}{c}\text { Case } \\
\# 3\end{array}$ & $\begin{array}{c}\text { Nominal } \\
\text { Frit }\end{array}$ & $\begin{array}{c}29-37 \\
\text { low } \eta\end{array}$ & $\begin{array}{c}\mathrm{T}_{\mathrm{L}} \text { limited at } 41 \%, \\
\text { nepheline limited at } 42 \%\end{array}$ \\
\hline $\begin{array}{c}\text { Case } \\
\# 4\end{array}$ & $\begin{array}{c}\text { Nominal } \\
\text { Frit }\end{array}$ & $\begin{array}{c}\text { homog } \\
30-38 \\
\mathrm{~T}_{\mathrm{L}}\end{array}$ & $\begin{array}{c}\text { Low } \eta \text { limited at } 40 \%, \\
\text { nepheline limited at } 43 \%\end{array}$ \\
\hline $\begin{array}{c}\text { Case } \\
\# 5\end{array}$ & $\begin{array}{c}\text { Nominal } \\
\text { Frit }\end{array}$ & $\begin{array}{c}31-35 \\
\text { low } \eta\end{array}$ & $\begin{array}{c}\text { Nepheline limited at } 42 \% \\
\text { and } \mathrm{T}_{\mathrm{L}} \text { limited at } 43 \%\end{array}$ \\
\hline
\end{tabular}

\subsection{1.a Case \#1: SB4 Baseline}

Applying sludge variation to current DWPF SB4 operations causes a significant reduction in the projected operating window to $29-36 \%$ WL over which all EVs can be processed; a $27-42 \% \mathrm{WL}$ interval was determined for the nominal SB4 composition (see Table 3). Current DWPF operations have not experienced any limitations based on the 34\% WL target; however, if variation in the incoming sludge is experienced (prior to the decant), then higher WLs may be restricted unless management decides to accept failing the process related constraint (low $\eta$ ) for the specific SME batch. Note that nepheline formation for any of the EVs is not predicted to be an issue until WLs of $42 \%$ or higher.

\subsection{1.b Case \#2: SB4 + 100K Gallon Decant}

The projected operating window over which all of the EVs could be processed for Case \#2 is 28 $37 \%$. At $38 \% \mathrm{WL}$ and higher, some of the EVs become limited by $\mathrm{T}_{\mathrm{L}}$, indicating that Frit 510 has a high degree of robustness to potential sludge variation from the Tank 40 decant. Low viscosity and nepheline predictions become limiting at 42 and $43 \% \mathrm{WL}$, respectively, for some of the EVs. The projected Variation Stage processing window after the Tank $40 \mathrm{H}$ decant is slightly larger than the baseline SB4 system prior to the decant. If higher WLs are of interest to potentially improve waste 
throughput, DWPF may be limited by $\mathrm{T}_{\mathrm{L}}$ predictions (between $38-41 \% \mathrm{WL}$ ), but a risk-based management decision could be made to process the specific SME batch. Nepheline formation should not be an issue for this system because it is suppressed to $43 \% \mathrm{WL}$ and higher for these EVs.

\subsection{1.c Case \#3: SB4 + 100K Gallon Decant $+3 w t \% ~ \mathrm{Na}_{2} \mathrm{O}$ Addition}

The addition of $3 \mathrm{wt} \% \mathrm{Na}_{2} \mathrm{O}$ to $\mathrm{SB} 4$ after the Tank $40 \mathrm{H}$ decant reduces the projected operating window to $29-37 \%$ WL; a $26-42 \%$ WL window was determined in the Nominal Stage assessment. $\mathrm{T}_{\mathrm{L}}$ and nepheline formation predictions do not become limiting until 41 and $42 \% \mathrm{WL}$, respectively. Based on the projected operating window alone, the $3 \mathrm{wt} \% \mathrm{Na}_{2} \mathrm{O}$ addition offers no significant advantage to DWPF; once sludge variation is applied, the projected operating windows for Case \#2 (Tank $40 \mathrm{H}$ decant) and Case $\# 3\left(3 \mathrm{wt} \% \mathrm{Na}_{2} \mathrm{O}\right.$ addition) are essentially the same. Unless a significant reduction in melt rate is observed once the Tank 40 decant is performed (Case \#2), addition of $\mathrm{Na}_{2} \mathrm{O}$ to the system through $\mathrm{NaOH}$ additions to improve melt rate may not be warranted. Note that the impacts of the Tank $40 \mathrm{H}$ decant or additions of $\mathrm{NaOH}$ on melt rate were not requested as part of this study.

\subsection{1.d Case \#4: SB4 + 100K Gallon Decant + ARP}

Because the Tank $40 \mathrm{H}$ decant is likely to occur and initiation of coupled operations (incorporation of ARP) is anticipated prior to the completion of SB4 processing, it is highly probable that this flowsheet option will be implemented in the facility. The addition of ARP after the Tank $40 \mathrm{H}$ decant has a projected operating window of $29-37 \% \mathrm{WL}$ in which all the EVs could be processed. $\mathrm{T}_{\mathrm{L}}$ predictions once again limit access to WLs greater than $37 \%$. The homogeneity constraint, which is important to a coupled operations flowsheet, limits WLs from 25 - 29\%; however, these lower WLs are of no practical concern. From a DWPF operating window perspective, Case \#4 is relatively similar to Case \#2 or Case \#3. More specifically, there is a 1 percentage point increase in WL over which all of the EVs could be processed with this option, which implies that Frit 510 would provide a little more flexibility for DWPF operations. The increased in the upper WL that defines the operating window as a result of ARP additions is consistent with previous results. ${ }^{13}$ The additional $\mathrm{Na}_{2} \mathrm{O}$ in the glass from ARP appears to reduce $\mathrm{T}_{\mathrm{L}}$ predictions. Conversely, $\mathrm{TiO}_{2}$ from the ARP increases $\mathrm{T}_{\mathrm{L}}$ predictions. The MAR results suggest that the ability of $\mathrm{Na}_{2} \mathrm{O}$ to lower $\mathrm{T}_{\mathrm{L}}$ predictions overcomes the increase in $\mathrm{T}_{\mathrm{L}}$ by $\mathrm{TiO}_{2}$. The impact of ARP addition on melt rate is not addressed in this paper study.

\subsection{1.e Case \#5: SB4 + 100K Gallon Decant $+3 w t \% \mathrm{Na}_{2} \mathrm{O}$ Addition + ARP}

Addition of ARP and $3 \mathrm{wt} \% \mathrm{Na}_{2} \mathrm{O}$ to $\mathrm{SB} 4$ after the decant results in a very narrow projected operating window over which all of the EVs can be processed $(31-35 \% \mathrm{WL})$. Based on the inability of Frit 510 to demonstrate compositional robustness to this flowsheet option, SRNL does not recommend this option. This recommendation may change once more formal compositional information is obtained after decanting or if ARP additions are modified (i.e., Na associated with cleaning the filters and transferring ARP is less than anticipated). Additional assessments could be performed to re-evaluate the feasibility of this option with the use of Frit 510 assuming significant compositional shifts are observed.

\subsubsection{Frit 510 Specifications coupled with the Nominal Sludge Options}

During the processing of SB4, analyses of select Frit 510 lots from the vendor have indicated that the levels of some of the major oxides and the impurity levels of other critical oxides are outside of the compositional tolerances. A previous MAR assessment of an "out of spec" Frit 510 suggests that 
there is little or no impact on the operating window when coupled with the current nominal SB4 baseline composition. ${ }^{14}$ This result was based on the use of a single frit composition (Frit 510 Lot 006), which was low in $\mathrm{B}_{2} \mathrm{O}_{3}$ content (12.3\% measured versus $14 \%$ target) and contained $1.37 \mathrm{wt} \%$ $\mathrm{Al}_{2} \mathrm{O}_{3}$ as an impurity. In this section, EVs defined by the Frit 510 procurement specifications were used with the nominal SB4 sludge options to evaluate the impact on the projected operating windows.Table 7 summarizes the impact of possible frit variation (within the current frit procurement specifications) to each of the nominal SB4 processing options being considered in this study. In order to assess the impact of potential variation in the Frit 510 composition on the projected operating windows, the results of the Nominal Stage assessment (nominal Frit 510 and nominal sludge compositions) will be used as a baseline (see Table 3).

Table 6. MAR Assessment of Frit 510 Specifications Coupled with Nominal SB4 Compositions.

\begin{tabular}{||c|c|c|c||}
\hline $\begin{array}{c}\text { SB4 } \\
\text { Option }\end{array}$ & $\begin{array}{c}\text { Variation } \\
\text { Stage }\end{array}$ & $\begin{array}{c}\text { Projected } \\
\text { Operating } \\
\text { Window (WL) }\end{array}$ & $\begin{array}{c}\text { Constraints at Higher } \\
\text { WLs }\end{array}$ \\
\hline $\begin{array}{c}\text { Case } \\
\# 1\end{array}$ & $\begin{array}{c}\text { Frit } \\
\text { Specifications }\end{array}$ & $\begin{array}{c}\text { homog } \\
27-36 \\
\text { low } \eta\end{array}$ & $\begin{array}{c}\text { nepheline limited at } 42 \% \\
\mathrm{~T}_{\mathrm{L}} \text { limited at } 45 \%\end{array}$ \\
\hline $\begin{array}{c}\text { Case } \\
\# 2\end{array}$ & $\begin{array}{c}\text { Frit } \\
\text { Specifications }\end{array}$ & $\begin{array}{c}25-40 \\
\mathrm{~T}_{\mathrm{L}}\end{array}$ & $\begin{array}{c}\text { low } \eta \text { limited at } 42 \%, \\
\text { nepheline limited at } 44 \%\end{array}$ \\
\hline $\begin{array}{c}\text { Case } \\
\# 3\end{array}$ & $\begin{array}{c}\text { Frit } \\
\text { Specifications }\end{array}$ & $\begin{array}{c}26-36 \\
\text { low } \eta\end{array}$ & $\begin{array}{c}\text { nepheline limited at } 43 \%, \\
\mathrm{~T}_{\mathrm{L}} \text { limited at } 44 \%\end{array}$ \\
\hline $\begin{array}{c}\text { Case } \\
\# 4\end{array}$ & $\begin{array}{c}\text { Frit } \\
\text { Specifications }\end{array}$ & $\begin{array}{c}27-39 \\
\text { low } \eta\end{array}$ & $\begin{array}{c}\mathrm{T}_{\mathrm{L}} \text { limited at } 42 \%, \\
\text { nepheline limited at } 44 \%\end{array}$ \\
\hline $\begin{array}{c}\text { Case } \\
\# 5\end{array}$ & Frit & $\begin{array}{c}\text { homog } \\
28-34 \\
\text { Specifications } \eta\end{array}$ & $\begin{array}{c}\text { nepheline limited at } 42 \%, \\
\mathrm{~T}_{\mathrm{L}} \text { limited at } 47 \%\end{array}$ \\
\hline
\end{tabular}

The magnitude of the impact of these compositional extremes in the frit on the projected operating windows appears to be flowsheet dependent. Application of the potential frit variation to the nominal Frit 510 flowsheet options that are low viscosity limited (Case \#1, Case \#3 and Case \#5 - see Table 3) generally leads to a considerable reduction (6 percentage points) in the upper WLs that can be attained. For example, consider the Frit 510 - Case \#1 scenario in Table 3, in which the projected operating window is $27-42 \%$ WL. Both low viscosity and nepheline limit access to higher WLs. Application of the frit procurement specifications to the nominal Case \#1 sludge results in a projected operating window of $27-36 \%$ with predictions of low viscosity being the limiting constraint. These results suggest that even within the procurement specifications, there are combinations of frit components that could lead to severe negative impacts on the projected operating windows.

For Case \#2 and Case \#4 (Table 3), which are initially $\mathrm{T}_{\mathrm{L}}$ limited, the application of the frit specifications has less of an impact resulting in a $1-3$ percentage point reduction. For example, consider the Frit 510 - Case \#2 scenario. The Nominal Stage assessment indicates that this option has a projected operating window of $25-41 \%$ and is limited by predictions of $T_{L}$ at higher WLs. Application of the frit procurement specifications to the nominal Case \#2 sludge results in a projected operating window, which is only reduced by 1 percentage point $(25-40 \%)$. As in the Nominal Stage assessment, access to higher WLs is limited by predictions of $T_{L}$. 


\subsubsection{Frit 510 Specifications coupled with Sludge Variation}

This section addresses the impacts of both sludge variation and frit variation on the projected operating windows. More specifically, each of the EVs defined by the frit procurement specifications was coupled with each of the EVs defined by the applied sludge variation. Although the application of "double variation" could be viewed as an aggressive approach, the results do provide insight into the potential SME acceptability issues during future processing of SB4 after the Tank $40 \mathrm{H}$ decant (where sludge compositional uncertainties are greater) coupled with possible frit compositional variation (within the procurement specifications).

As shown in Table 7, the projected operating windows of DWPF could be severely restricted if substantial variation in the sludge composition were realized when coupled with variation in Frit 510 (even within the current specifications). All of the projected operating windows are extremely small or non-existent, as in Case \#5. Based on recent processing of SB4 (Case \#1), it is unlikely that this situation will be experienced prior to the Tank $40 \mathrm{H}$ decant and it is doubtful that DWPF will experience the extreme variations in sludge applied in this assessment. Processing SB4 prior to the Tank $40 \mathrm{H}$ decant will more likely be impacted by variation in the frit composition (see Section 4.2.2). It should be noted that the assessments in Section 4.2.2 only apply the frit procurement specifications. DWPF has recently received frits that are not only outside the specifications, but have impurity concentrations exceeding specific requirements. A supplemental memo will address the impact of larger frit procurement specification uncertainties and/or the inclusion of significant impurity concentrations $\left(\mathrm{Al}_{2} \mathrm{O}_{3}\right.$ and/or $\left.\mathrm{ZrO}_{2}\right)$ on the projected operating windows for the various flowsheet options.

Table 7. MAR Assessment of Frit 510 Specifications Coupled with Sludge Variation

\begin{tabular}{||c|c|c|c||}
\hline $\begin{array}{c}\text { SB4 } \\
\text { Option }\end{array}$ & $\begin{array}{c}\text { Variation } \\
\text { Stage }\end{array}$ & $\begin{array}{c}\text { Projected } \\
\text { Operating } \\
\text { Window (WL) }\end{array}$ & $\begin{array}{c}\text { Constraints at Higher } \\
\text { WLs }\end{array}$ \\
\hline $\begin{array}{c}\text { Case } \\
\# 1\end{array}$ & $\begin{array}{c}\text { Frit } \\
\text { Specifications }\end{array}$ & $\begin{array}{c}\text { homog } \\
\text { low } \eta\end{array}$ & $\begin{array}{c}\mathrm{T}_{\mathrm{L}} \text { limited at } 40 \% \mathrm{WL}, \\
\text { nepheline limited at } 41 \%\end{array}$ \\
\hline $\begin{array}{c}\text { Case } \\
\# 2\end{array}$ & $\begin{array}{c}\text { Frit } \\
\text { Specifications }\end{array}$ & $\begin{array}{c}28-35 \\
\text { low } \eta\end{array}$ & $\begin{array}{c}\mathrm{T}_{\mathrm{L}} \text { limited at } 37 \% \mathrm{WL}, \\
\text { nepheline limited at } 42 \%\end{array}$ \\
\hline $\begin{array}{c}\text { Case } \\
\# 3\end{array}$ & $\begin{array}{c}\text { Frit } \\
\text { Specifications }\end{array}$ & $\begin{array}{c}29-31 \\
\text { low } \eta\end{array}$ & $\begin{array}{c}\mathrm{T}_{\mathrm{L}} \text { limited at } 40 \% \mathrm{WL}, \\
\text { nepheline limited at } 41 \%\end{array}$ \\
\hline $\begin{array}{c}\text { Case } \\
\# 4\end{array}$ & $\begin{array}{c}\text { Frit } \\
\text { homog } \\
\text { Specifications }\end{array}$ & $\begin{array}{c}30-33 \\
\text { low } \eta\end{array}$ & $\begin{array}{c}\mathrm{T}_{\mathrm{L}} \text { limited at } 38 \% \mathrm{WL}, \\
\text { nepheline limited at } 42 \%\end{array}$ \\
\hline $\begin{array}{c}\text { Case } \\
\# 5\end{array}$ & $\begin{array}{c}\text { Frit } \\
\text { Specifications }\end{array}$ & No window & $\begin{array}{c}\text { low } \eta \text { limited from } 31- \\
40 \% \mathrm{WL}, \mathrm{T}_{\mathrm{L}} \text { and } \\
\text { nepheline limited at } 41 \%\end{array}$ \\
\hline
\end{tabular}

\footnotetext{
h The term "double variation" refers to the application of both sludge variation (as defined in Table 4) and the variation associated with the frit procurement specifications. It should be noted that the variation in the sludge (as shown in Table 4) has not been doubled but the standard variation applied to the sludge has been added to the variation in the frit composition as defined by the frit procurement specifications.
} 
WSRC-STI-2008-00017

Revision 0

\subsection{Impact of the SB4 Flowsheet Changes on the SB4 Variability Study}

In order to satisfy the WAPS requirements a variability study must be conducted to demonstrate that the PCT/chemical composition correlation (i.e., $\Delta \mathrm{G}_{\mathrm{P}}$ model) currently utilized by DWPF applies to the SB4 glass composition region to be processed in DWPF. ${ }^{6,7}$ Prior to the initiation of a formal experimental study, the ComPro ${ }^{\mathrm{TM}}$ database is first reviewed to determine if historical glasses are located within the compositional regions of interest for the different cases. ${ }^{4,5}$ If a sufficient number of historical glasses are found within the compositional regions defined by the revised SB4 - Frit 510 flowsheet modifications, then an experimental study may not be required. If an adequate number of historical glasses are not found, then an experimental study needs to be designed and implemented to support the WAPS requirements.

Based on the Nominal and Traditional Variation assessments, LWO may elect to implement one or more of these options as the results suggest that all of the flowsheet options are viable (some caution should be exercised if Case \#5 is to be pursued). Therefore, a series of "if then" statements was developed for $\mathrm{JMP}^{\mathrm{TM}}$ to search the ComPro ${ }^{\mathrm{TM}}$ database for historical glasses that may exist within the compositional regions defined by the various flowsheets. ${ }^{4,5}$ The "if then" statements were developed to capture not only the potential variation in sludge (as shown in Table 4), but also the possible frit variation (bounded by the specification limits for the major frit oxides) over WLs of interest (in line with the "double variation" concept developed in Section 4.2.3).

Based on this electronic search, approximately 12 glasses were identified that are located within at least one of the five glass regions. These historical glasses are primarily from the previous SB4 variability study (using Frit 503 and Frit 418) and the PCT responses from both the quenched and centerline canister cooled glasses are acceptable $e^{\mathrm{i}}$ and predictable by the current durability model. ${ }^{15-17}$ While these glasses meet the intent of the variability study requirements for SB4 current operations, the extent of the coverage that these glasses have in the newly defined glass regions is of concern. Therefore, SRNL is recommending that and has initiated a supplemental experimental variability study be performed to support the various SB4 flowsheet options that may be implemented for future SB4 operations in DWPF.

Given the compositional range of the historical glasses and the acceptable durability response of the historical SB4 glasses, the use of EVs to define or develop the supplementary SB4 study is not deemed warranted. Therefore, the nominal compositions of the five cases of interest in this study will be used to define specific glasses to fabricate and characterize.

The glass selection process utilized two primary inputs: (1) the projected operating windows over which acceptable glasses would be produced (results of the Nominal Stage MAR assessments reported in Section 4.1) and (2) a review of the five nominal sludge compositions to determine compositional similarities. A review of the projected sludge compositions (Table 1) and the Nominal Stage assessment (Table 3) indicates that Case \#1 and Case \#3 are very similar. Due to the compositional similarities, six glasses were selected using both sludge options over a WL interval of interest to both systems $(32-42 \% \mathrm{WL})$ in "alternating" $4 \% \mathrm{WL}$ increments; when coupled with Frit 510, Case \#1 targeted 34, 38, and 42\% WL and Case \#3 targeted WLs of 32, 36, and 40\%. ${ }^{\mathrm{j}} \quad$ Table 7

\footnotetext{
${ }^{\mathrm{i}}<1.6 \mathrm{~g} / \mathrm{L}$ normalized boron release compared to $16.695 \mathrm{~g} / \mathrm{L}$ for the Environmental Assessment (EA) glass.

${ }^{\mathrm{j}}$ Although lower than the $34 \%$ WL target of current SB4 operations, 32\% WL was chosen as a "bounding" composition in case lower WLs are observed due to blending uncertainties and/or the need to lower WLs for future SB4 operations. The glass with a target of $42 \%$ WL could also be viewed as a "bounding" case.
} 
summarizes the nominal projected compositions of these six glasses. The study of these glasses provides an opportunity to assess the entire WL interval of interest to DWPF as well as an opportunity to identify any issues related to the slight differences in the nominal sludge compositions of Case \#1 and Case \#3, although none would be anticipated.

Case \#2 represents a relatively unique sludge as it has the lowest $\mathrm{Na}_{2} \mathrm{O}$ content of the options being evaluated. Based on the Nominal Stage projected operating window for this system $(25-41 \% \mathrm{WL})$, four Frit 510 based glasses were selected targeting WLs of 32, 35, 38, and 41\% as shown in Table 9. Again, this WL interval spans the operating window of interest and will provide insight into any potential durability issues associated with the Tank $40 \mathrm{H}$ decant option.

The addition of $\mathrm{TiO}_{2}$ from ARP makes Cases \#4 and \#5 unique from the "sludge-only" options. Although the $\mathrm{TiO}_{2}$ concentrations in both nominal sludge projections are essentially identical, the addition of the $3 \% \mathrm{Na}_{2} \mathrm{O}$ to the coupled flowsheet makes Case $\# 5$ unique unto itself. Therefore, four glasses were selected for Case \#4 and four were selected for Case \#5 targeting 32, 35, 38, and 41\% WL. Although the Case \#5 glass is limited by low viscosity at the nominal $41 \% \mathrm{WL}$, it will provide additional support to the variability study. Table 10 summarizes the nominal projected compositions of these Case \#4 and Case \#5 based glasses.

The eighteen glasses will be fabricated and characterized according to the Task Technical and QA plan to demonstrate that the glasses are both acceptable and predictable by the current process control models for durability. ${ }^{3}$ The results will be reported in a subsequent report. 
Table 8. Target Glass Compositions (wt\%) for Case \#1 and Case \#3

\begin{tabular}{||c|c|c|c|c|c|c||}
\hline & \multicolumn{3}{|c|}{ Case \#1 } & \multicolumn{3}{c|}{ Case \#3 } \\
\hline Glass ID & SB4VAR11 & SB4VAR12 & SB4VAR13 & SB4VAR31 & SB4VAR32 & SB4VAR33 \\
\hline $\mathrm{Frit}$ & 510 & 510 & 510 & 510 & 510 & 510 \\
\hline $\mathrm{WL}$ & 34 & 38 & 42 & 32 & 36 & 40 \\
\hline $\mathrm{Al}_{2} \mathrm{O}_{3}$ & 8.46 & 9.46 & 10.46 & 8.00 & 9.01 & 10.01 \\
\hline $\mathrm{B}_{2} \mathrm{O}_{3}$ & 9.24 & 8.68 & 8.12 & 9.52 & 8.96 & 8.40 \\
\hline $\mathrm{BaO}$ & 0.03 & 0.03 & 0.03 & 0.02 & 0.03 & 0.03 \\
\hline $\mathrm{CaO}$ & 0.93 & 1.04 & 1.15 & 0.88 & 0.99 & 1.10 \\
\hline $\mathrm{Ce}_{2} \mathrm{O}_{3}$ & 0.02 & 0.02 & 0.03 & 0.02 & 0.02 & 0.03 \\
\hline $\mathrm{Cr}_{2} \mathrm{O}_{3}$ & 0.05 & 0.06 & 0.07 & 0.05 & 0.06 & 0.06 \\
\hline $\mathrm{CuO}$ & 0.02 & 0.02 & 0.02 & 0.02 & 0.02 & 0.02 \\
\hline $\mathrm{Fe}_{2} \mathrm{O}_{3}$ & 9.62 & 10.75 & 11.88 & 9.13 & 10.27 & 11.41 \\
\hline $\mathrm{K}_{2} \mathrm{O}$ & 0.12 & 0.13 & 0.15 & 0.11 & 0.13 & 0.14 \\
\hline $\mathrm{La}_{2} \mathrm{O}_{3}$ & 0.02 & 0.02 & 0.02 & 0.02 & 0.02 & 0.02 \\
\hline $\mathrm{Li}_{2} \mathrm{O}$ & 5.28 & 4.96 & 4.64 & 5.44 & 5.12 & 4.80 \\
\hline $\mathrm{MgO} \mathrm{O}$ & 0.91 & 1.02 & 1.13 & 0.87 & 0.97 & 1.08 \\
\hline $\mathrm{MnO}$ & 1.93 & 2.16 & 2.39 & 1.83 & 2.06 & 2.29 \\
\hline $\mathrm{Na}_{2} \mathrm{O}$ & 12.26 & 12.76 & 13.26 & 11.93 & 12.42 & 12.92 \\
\hline $\mathrm{NiO}_{\mathrm{PbO}}$ & 0.54 & 0.60 & 0.66 & 0.51 & 0.57 & 0.63 \\
\hline $\mathrm{SO}_{4}$ & 0.02 & 0.02 & 0.03 & 0.02 & 0.02 & 0.03 \\
\hline $\mathrm{SiO}_{2}$ & 0.45 & 0.50 & 0.55 & 0.32 & 0.36 & 0.40 \\
\hline $\mathrm{TiO}_{2}$ & 0.01 & 0.01 & 0.02 & 0.01 & 0.01 & 0.02 \\
\hline $\mathrm{U}_{3} \mathrm{O}_{8}$ & 2.94 & 3.28 & 3.63 & 2.79 & 3.13 & 3.48 \\
\hline $\mathrm{ZnO}$ & 0.03 & 0.03 & 0.03 & 0.02 & 0.03 & 0.03 \\
\hline $\mathrm{ZrO}_{2}$ & 0.03 & 0.03 & 0.03 & 0.03 & 0.03 & 0.03 \\
\hline $\mathrm{Total}$ & 100.00 & 100.00 & 100.00 & 100.00 & 100.00 & 100.00 \\
\hline \hline
\end{tabular}


Table 9. Target Glass Compositions (wt \%) for Case \#2

\begin{tabular}{|c|c|c|c|c|}
\hline & \multicolumn{4}{|c|}{ Case \#2 } \\
\hline & SB4VAR21 & SB4VAR22 & SB4VAR23 & SB4VAR24 \\
\hline Frit & 510 & 510 & 510 & 510 \\
\hline WL & 32 & 35 & 38 & 41 \\
\hline$\overline{\mathrm{Al}_{2} \mathrm{O}_{3}}$ & 8.31 & 9.09 & 9.86 & 10.64 \\
\hline $\mathrm{B}_{2} \mathrm{O}_{3}$ & 9.52 & 9.10 & 8.68 & 8.26 \\
\hline $\mathrm{BaO}$ & 0.02 & 0.03 & 0.03 & 0.03 \\
\hline $\mathrm{CaO}$ & 0.91 & 1.00 & 1.09 & 1.17 \\
\hline $\mathrm{Ce}_{2} \mathrm{O}_{3}$ & 0.02 & 0.02 & 0.03 & 0.03 \\
\hline $\mathrm{Cr}_{2} \mathrm{O}_{3}$ & 0.05 & 0.06 & 0.06 & 0.07 \\
\hline $\mathrm{CuO}$ & 0.02 & 0.02 & 0.02 & 0.02 \\
\hline $\mathrm{Fe}_{2} \mathrm{O}_{3}$ & 9.47 & 10.36 & 11.25 & 12.14 \\
\hline $\mathrm{K}_{2} \mathrm{O}$ & 0.12 & 0.13 & 0.14 & 0.15 \\
\hline $\mathrm{La}_{2} \mathrm{O}_{3}$ & 0.02 & 0.02 & 0.02 & 0.02 \\
\hline $\mathrm{Li}_{2} \mathrm{O}$ & 5.44 & 5.20 & 4.96 & 4.72 \\
\hline $\mathrm{MgO}$ & 0.90 & 0.98 & 1.07 & 1.15 \\
\hline $\mathrm{MnO}$ & 1.90 & 2.08 & 2.26 & 2.44 \\
\hline $\mathrm{Na}_{2} \mathrm{O}$ & 10.98 & 11.26 & 11.54 & 11.82 \\
\hline $\mathrm{NiO}$ & 0.53 & 0.58 & 0.63 & 0.68 \\
\hline $\mathrm{PbO}$ & 0.02 & 0.02 & 0.02 & 0.03 \\
\hline $\mathrm{SO}_{4}$ & 0.32 & 0.35 & 0.38 & 0.41 \\
\hline $\mathrm{SiO}_{2}$ & 48.49 & 46.47 & 44.46 & 42.44 \\
\hline $\mathrm{TiO}_{2}$ & 0.01 & 0.01 & 0.02 & 0.02 \\
\hline $\mathrm{U}_{3} \mathrm{O}_{8}$ & 2.89 & 3.16 & 3.43 & 3.70 \\
\hline $\mathrm{ZnO}$ & 0.03 & 0.03 & 0.03 & 0.03 \\
\hline $\mathrm{ZrO}_{2}$ & 0.03 & 0.03 & 0.03 & 0.03 \\
\hline Total & 100.00 & 100.00 & 100.00 & 100.00 \\
\hline
\end{tabular}


Table 10. Target Glass Compositions (wt \%) for Case \#4 and Case \#5

\begin{tabular}{|c|c|c|c|c|c|c|c|c|}
\hline & \multicolumn{4}{|c|}{ Case \#4 } & \multicolumn{4}{|c|}{ Case \#5 } \\
\hline & SB4VAR41 & SB4VAR42 & SB4VAR43 & SB4VAR44 & SB4VAR51 & SB4VAR52 & SB4VAR53 & SB4VAR54 \\
\hline Frit & 510 & 510 & 510 & 510 & 510 & 510 & 510 & 510 \\
\hline WL & 32 & 35 & 38 & 41 & 32 & 35 & 38 & 41 \\
\hline $\mathrm{Al}_{2} \mathrm{O}_{3}$ & 8.00 & 8.75 & 9.50 & 10.25 & 7.71 & 8.43 & 9.15 & 9.88 \\
\hline $\mathrm{B}_{2} \mathrm{O}_{3}$ & 9.52 & 9.10 & 8.68 & 8.26 & 9.52 & 9.10 & 8.68 & 8.26 \\
\hline $\mathrm{BaO}$ & 0.02 & 0.03 & 0.03 & 0.03 & 0.02 & 0.03 & 0.03 & 0.03 \\
\hline $\mathrm{CaO}$ & 0.88 & 0.97 & 1.05 & 1.13 & 0.85 & 0.93 & 1.01 & 1.09 \\
\hline $\mathrm{Ce}_{2} \mathrm{O}_{3}$ & 0.02 & 0.03 & 0.03 & 0.03 & 0.02 & 0.02 & 0.03 & 0.03 \\
\hline $\mathrm{Cr}_{2} \mathrm{O}_{3}$ & 0.05 & 0.06 & 0.06 & 0.07 & 0.05 & 0.05 & 0.06 & 0.06 \\
\hline $\mathrm{CuO}$ & 0.02 & 0.02 & 0.02 & 0.02 & 0.02 & 0.02 & 0.02 & 0.02 \\
\hline $\mathrm{Fe}_{2} \mathrm{O}_{3}$ & 9.20 & 10.06 & 10.92 & 11.79 & 8.87 & 9.70 & 10.53 & 11.37 \\
\hline $\mathrm{K}_{2} \mathrm{O}$ & 0.11 & 0.12 & 0.13 & 0.15 & 0.11 & 0.12 & 0.13 & 0.14 \\
\hline $\mathrm{La}_{2} \mathrm{O}_{3}$ & 0.02 & 0.02 & 0.02 & 0.02 & 0.02 & 0.02 & 0.02 & 0.02 \\
\hline $\mathrm{Li}_{2} \mathrm{O}$ & 5.44 & 5.20 & 4.96 & 4.72 & 5.44 & 5.20 & 4.96 & 4.72 \\
\hline $\mathrm{MgO}$ & 0.86 & 0.94 & 1.02 & 1.10 & 0.83 & 0.90 & 0.98 & 1.06 \\
\hline $\mathrm{MnO}$ & 1.88 & 2.06 & 2.23 & 2.41 & 1.82 & 1.99 & 2.16 & 2.33 \\
\hline $\mathrm{Na}_{2} \mathrm{O}$ & 11.34 & 11.66 & 11.97 & 12.28 & 12.25 & 12.65 & 13.04 & 13.44 \\
\hline $\mathrm{NiO}$ & 0.52 & 0.57 & 0.62 & 0.67 & 0.50 & 0.55 & 0.60 & 0.65 \\
\hline $\mathrm{PbO}$ & 0.02 & 0.02 & 0.03 & 0.03 & 0.02 & 0.02 & 0.02 & 0.03 \\
\hline $\mathrm{SO}_{4}$ & 0.35 & 0.38 & 0.41 & 0.45 & 0.35 & 0.38 & 0.41 & 0.45 \\
\hline $\mathrm{SiO}_{2}$ & 48.46 & 46.44 & 44.42 & 42.40 & 48.43 & 46.40 & 44.38 & 42.36 \\
\hline $\mathrm{TiO}_{2}$ & 0.43 & 0.47 & 0.51 & 0.55 & 0.43 & 0.47 & 0.51 & 0.55 \\
\hline $\mathrm{U}_{3} \mathrm{O}_{8}$ & 2.80 & 3.06 & 3.32 & 3.59 & 2.70 & 2.95 & 3.21 & 3.46 \\
\hline $\mathrm{ZnO}$ & 0.03 & 0.03 & 0.03 & 0.03 & 0.02 & 0.03 & 0.03 & 0.03 \\
\hline $\mathrm{ZrO}_{2}$ & 0.03 & 0.03 & 0.03 & 0.04 & 0.03 & 0.03 & 0.03 & 0.04 \\
\hline Total & 100.00 & 100.00 & 100.00 & 100.00 & 100.00 & 100.00 & 100.00 & 100.00 \\
\hline
\end{tabular}




\subsection{Summary}

SB4 is currently being processed in the DWPF using Frit 510 . The slurry pumps in Tank $40 \mathrm{H}$ are experiencing in-leakage of bearing water, which is causing the sludge slurry feed in Tank $40 \mathrm{H}$ to become dilute at a rapid rate. At the present time, the DWPF is removing this dilution water by performing caustic boiling during the SRAT cycle. In order to alleviate prolonged SRAT cycle times, which may eventually impact canister production rates, decant scenarios of varying amounts of supernate have been proposed for Tank $40 \mathrm{H}$. These potential SB4 flowsheet modifications (i.e., $100 \mathrm{~K}$ gallon decant, potential additions of $\mathrm{Na}_{2} \mathrm{O}$, or transferring to a coupled operations flowsheet) could result in significant compositional shifts in the SB4 system. This study provided an assessment of the impact of these compositional changes to the projected glass operating windows and to the variability study for the Frit 510 - SB4 system. The influence of the compositional changes on melt rate was not requested or assessed in this study.

\subsection{Nominal and Variation Stage Assessments}

Based on the projected compositions, both Nominal and Variation Stage assessments were utilized to determine the impact on DWPF projected operation windows. The results of the Nominal Stage assessment indicate very little difference among the various flowsheet options. All of the flowsheets provide DWPF with the possibility of targeting WLs from the low 30s to low 40s with Frit 510. In general, the Tank $40 \mathrm{H}$ decant has a slightly negative impact on the operating window, but DWPF still has the ability to target current WLs (34\%) and higher WLs if needed. While the decant does not affect practical WL targets in DWPF, melt rate could be reduced due to the lower $\mathrm{Na}_{2} \mathrm{O}$ content. If true, the addition of $3 \mathrm{wt} \% \mathrm{Na}_{2} \mathrm{O}$ to the glass system may regain melt rate, assuming that the source of alkali does not affect the impact of the alkali on melt rate. Addition of ARP to a decanted SB4 flowsheet also appears to be viable based on the projected operating windows. The addition of both $\mathrm{ARP}$ and $3 \mathrm{wt} \% \mathrm{Na}_{2} \mathrm{O}$ to a decanted Tank 40 sludge may be problematic due to the high sodium content.

Although the Nominal Stage assessment provides reasonable operating windows, introduction of potential sludge and/or frit compositional variation has a significant negative impact. The magnitude of the impact of frit compositional extremes (defined by the frit procurement specifications) on the projected operating windows appears to be flowsheet dependent. The more severe impacts (a 6 percentage point reduction in the upper WLs that can be achieved relative to the Nominal Stage window) occur with systems that are low viscosity limited. For those cases which are $\mathrm{T}_{\mathrm{L}}$ limited, only a $1-2$ percentage point reduction is projected.

When both frit and sludge variations are applied, the paper study results indicate that DWPF processing could be severely restricted. The projected operating windows are extremely small or non-existent, as in Case \#5. Although the application of "double variation" could be viewed as an aggressive approach, the results do provide insight into the potential SME acceptability issues during future processing of SB4 after the Tank $40 \mathrm{H}$ decant (where sludge compositional uncertainties are greater) coupled with possible frit compositional variation (within the procurement specifications).

\subsection{Impact of the SB4 Flowsheet Changes on the SB4 Variability Study}

Based on an electronic search of ComPro ${ }^{\mathrm{TM}}$, approximately 12 historical glasses were identified that are located within at least one of the five glass regions defined by the proposed SB4 flowsheet options. These historical glasses are primarily from the previous SB4 variability 
studies (using Frit 503 or Frit 418), and the PCT responses from both the quenched and centerline canister cooled glasses are acceptable and predictable by the current durability model. ${ }^{15-17}$ While these glasses meet the requirements of the variability study for SB4 current operations, there is some concern over the coverage that these glasses provide in the newly defined glass regions. Therefore, SRNL recommends that a supplemental, experimental variability study be performed to support the various SB4 flowsheet options that may be implemented for future SB4 operations in DWPF. Eighteen glasses have been selected based on nominal sludge projections representing the current as well as the proposed flowsheets over a WL interval of interest to DWPF (32 $42 \%$ ). These eighteen glasses will be fabricated and characterized to demonstrate that the glasses are both acceptable and predictable by the current process control models for durability.

\subsection{References}

1. M.E. Stone, F.C. Raszewski, B.R. Pickenheim, T.B. Edwards, and D.K. Peeler, "Impacts of a Tank 40 Supernate Decant to DWPF Glass Formulation and CPC Processing: A Preliminary Assessment for SB4," Savannah River National Laboratory, Aiken, SC, Report No. SRNL-PSE-2007-00257, November 2007.

2. B.A. Davis, "SB4 Flowsheet and Variability Studies for Tank 40H 100,000 Gallon Decant Technical Task Request," Liquid Waste Organization, Aiken, SC, Report No. HLW-DWPF-TTR-2008-0009, Rev. 0, December 2007.

3. F.C. Raszewski and M.E. Stone, "SB4 Flowsheet and Variability Studies for Tank 40H 100,000 Gallon Decant Task Technical and QA Plan," Savannah River National Laboratory, Aiken, SC, Report No. WSRC-STI-2007-00700 Rev. 0, January 2008.

4. K.M. Fox, D.K. Peeler, and T.B. Edwards, "Request for QA Approval of Nepheline Database," Washington Savannah River Company, Aiken, SC, Report No. SRNL-PSE2006-00053, 2006.

5. A.S. Taylor, T.B. Edwards, J.C. George, T.K. Snyder, and D.K. Peeler, "The SRNL Composition - Properties (ComPro ${ }^{\mathrm{TM}}$ ) Database," Westinghouse Savannah River Company, Aiken, SC, Report No. WSRC-RP-2004-00704, Revision 0, 2004.

6. "Standard Test Methods for Determining Chemical Durability of Nuclear, Hazardous, and Mixed Waste Glasses and Multiphase Glass Ceramics: The Product Consistency Test (PCT)," ASTM International, West Conshohocken, PA, Report No. ASTM C 1285-02, 2002.

7. C.M. Jantzen, J.B. Picket, K.G. Brown, T.B. Edwards, and D.C. Beam, "Process/Product Models for the Defense Waste Processing Facility (DWPF): Part I. Predicting Glass Durability from Composition Using a Thermodynamic Hydration Energy Reaction Model (THERMO)," Westinghouse Savannah River Company, Aiken, SC, Report No. WSRC-TR-93-672, Rev. 1, September 1995.

8. J.W. Ray, A.V. Staub, M.J. Plodinec, and S.L. Marra, "DWPF Glass Product Control Program," Westinghouse Savannah River Company, Aiken, SC, Report No. WSRC-IM91-116-6, Rev. 5, 1995. 
9. K.G. Brown, R.L. Postles, and T.B. Edwards, "SME Acceptability Determination for DWPF Process Control," Westinghouse Savannah River Company, Aiken, SC, Report No. WSRC-TR-95-00364, Rev. 5, 2006.

10. P.L. Bovan, "Glass Analyses and Physical Property Measurements for DWPF Frit," Washington Savannah River Company, Aiken, SC, Report No. X-SOW-S-00001, Rev. 0, May 2007.

11. P.L. Bovan, "Specification for Procurement of DWPF Frit," Washington Savannah River Company, Aiken, Report No. X-SPP-S-00018, Rev. 7, December 2007.

12. JMP ${ }^{\mathrm{TM}}$ Version 6.0.3, SAS Institute Inc., Cary, NC, 2005.

13. D.K. Peeler and T.B. Edwards, "The Impact of the Actinide Removal Process (ARP) on the Sludge Batch 4 Projected Operating Windows," Westinghouse Savannah River Company, Aiken, SC, Report No. WSRC-TR-2005-00123, Revision 0, 2005.

14. D.K. Peeler, to P. L. Bovan, "Ferro Frit 510 Lot 006 - Out of Spec Results Path Forward," January 14, 2008, Email.

15. K.M. Fox, T.B. Edwards, D.K. Peeler, D.R. Best, I.A. Reamer, and R.J. Workman, "High Level Waste (HLW) Sludge Batch 4 (SB4) Variability Study," Washington Savannah River Company, Aiken, SC, Report No. WSRC-STI-2006-00204, Revision 0, 2006.

16. K.M. Fox, T.B. Edwards, D.K. Peeler, D.R. Best, I.A. Reamer, and R.J. Workman, "High Level Waste (HLW) Sludge Batch 4 (SB4) with Frit 418: Results of a Phase II Variability Study," Washington Savannah River Company, Aiken, SC, Report No. WSRC-STI-2006-00329, Revision 0, 2006.

17. S.L. Marra and C.M. Jantzen, "Characterization of Projected DWPF Glass Heat Treated to Simulate Canister Centerline Cooling," Westinghouse Savannah River Company, Aiken, SC, Report No. WSRC-TR-92-142, Revision 1, 1993. 


\section{Distribution:}

C.J. Bannochie, 773-42A

A.B. Barnes, 999-W

D.R. Best, 786-1A

D.B. Burns, 786-5A

D.A. Crowley, 999-W

B.A. Davis, 704-27S

R.E. Edwards, 773-A

T.B. Edwards, 999-W

H.H. Elder, 766-H

T.L. Fellinger, 704-26S

K.M. Fox, 999-W

J.M. Gillam, 766-H

J.C. Griffin, 773-A

B.A. Hamm, 766-H

C.C. Herman, 999-W

J.F. Iaukea, 704-30S

J.E. Marra, 773-A

R.T. McNew, 704-27S

T.A. Nance, $773-42 \mathrm{~A}$

J.D. Newell, 999-W

J.E. Occhipinti, 704-S

D.K. Peeler, 999-W

F.C. Raszewski, 999-W

J.W. Ray, 704-S

I.A. Reamer, 999-1W

H.B. Shah, 766-H

M.E. Smith, 999-W

M.E. Stone, 999-W

J. Stuberfield, 766-H

M.F. Williams, 999-1W

R.J. Workman, 999-1W

A.L. Youchak, 999-W 